HoST - Journal of History of Science and Technology

Vol. 13, no. 2, December 2019, pp. 86-117

10.2478/host-2019-0014

SPECIAL ISSUE

ANIMALS, SCIENCE AND TECHNOLOGY: MULTISPECIES HISTORIES OF SCIENTIFIC

AND SOCIOTECHNICAL KNOWLEDGE-PRACTICES

\title{
The Social Evolving: Sociogenomics on the Wings of Social Insects
}

\author{
Sainath Suryanarayanan \\ University of Wisconsin-Madison \\ ssuryanaraya@wisc.edu
}

\begin{abstract}
This paper excavates the epistemological and ontological foundations of a rapidly emerging field called sociogenomics in relation to the development of social insects as models of social behavior. Its center-stage is "the genome," where social and environmental information and genetic variation interact to influence social behavior through dynamic shifts in gene expression across multiple bodies and time-scales. With the advent of whole-genome sequencing technology, comparative genomics, and computational tools for mining patterns of association across widely disparate datasets, social insects are being experimented with to identify genetic networks underlying autism, novelty-seeking and aggression evolutionarily shared with humans. Drawing on the writings of key social insect biologists, and historians and philosophers of science, I investigate how the historical development of social insect research on wasps, ants and bees shape central approaches in sociogenomics today, in particular, with regards to shifting understandings of "the individual" in relation to "the social."
\end{abstract}

Keywords: sociogenomics; social insect; sociobiology; postgenomics; biology and society 


\title{
Introduction
}

\begin{abstract}
...I believe that the difficulty in studying the genetic basis of social behavior demands a bold, new initiative, which I call sociogenomics. In essence, this means taking a wide-ranging approach to identify genes that influence social behavior, determining the influence of these genes on underlying neural and endocrine mechanisms and exploring the effects of the environment-particularly the social environment-on gene action.
\end{abstract}

On 26 November 2018, scientific and mass-media outlets across the world were in shock with the announcement by a Chinese scientist claiming to have successfully created the first "gene edited" human babies. ${ }^{2}$ Utilizing an emerging gene-manipulation technology called CRISPRCAS, Dr. He Jiankui claimed to have modified in human embryos a key gene that is required for producing an immune cell receptor targeted by the human immunodeficiency virus (HIV). Dr. Jiankui contended that by editing the genomes of twin baby girls in this manner, he had ensured that they would be resistant to AIDS for the rest of their lives, and that they would pass on the engineered mutation to their future offspring. Whether or not these first CRISPRedited humans enhanced to withstand HIV infection actually exist, the accompanying mixture of horror, awe, and anxiety is real. Nearly every day, the 24-7 news cycle and sci-fi media amplify advances in gene editing, genomics, and epigenetics, and fuel public anticipations that range from utopian imaginaries of genomically enhanced humans living significantly longer and higher quality lives to dystopian futures where eugenic histories of Nazism re-appear in more terrifying and oppressive forms.

Sociologists and historians of science and technology are attending keenly to this "postgenomic" 3 moment exemplified by Dr. Jiankui's controversial claim-a period in the aftermath of the sequencing of "the human genome," which is ostensibly reshaping how we understand and transform life itself. Powerful institutions spanning the public-to-private continuum in sectors including biomedicine, agriculture, military, and environment have become interested in capitalizing on the deoxyribo-nucleic acid (DNA) sequences being generated and analyzed. At the same time, as scientists working across these institutions grapple with the burgeoning complexity of multi-genomic information, their efforts to understand the meanings of these sequences have yet to deliver definitively on the hype and hope being invested into postgenomic imaginaries.

1 Gene E. Robinson, "From Society to Genes with the Honey Bee," American Scientist 86, no. 5 (September-October 1998): 456-462, on 462.

2 Dennis Normile, "Shock greets claim of CRISPR-edited babies," Science 362, no. 6418 (2018): 978979.

3 Sara S. Richardson and Hallam Stevens, eds., Postgenomics: Perspectives on Biology After the Genome (Durham and London: Duke University Press, 2015). 
Indicative and constitutive of the rapidly evolving state of affairs that is afoot across multiple fields of scientific knowledge, a bold new field of research—called "sociogenomics" or "social genomics"- has emerged over the last two decades. Its practitioners, which include economists, political scientists, sociologists, genome biologists, and bioinformaticists, seek to collaboratively understand and manipulate the: (1) the role of genes in shaping social dynamics; (2) the role of the social environment on gene action; and (3) the interaction between organismal genes and environments in shaping patterns of social behavior. Sociogenomics has garnered greatest attention among promoters and critics mainly for its implications for policy and future human society. For example, sociogenomic researchers seek to make robust predictions of social outcomes such as impulse control, aggressive behavior, educational attainment, gregariousness, entrepreneurialism, and novelty-seeking. ${ }^{4}$

Science and technology studies (STS) scholar Catherine Bliss ${ }^{5}$ examines the emergence of human sociogenomics as an interdiscipline and its implications for justice, ethics and governance. In this paper, I show the significance of attending also to the more-than-human ${ }^{6}$ relations shaping the development of sociogenomics. In particular, I argue that social insect studies play a crucial role-as epistemological and ontological drivers-in the rise and continuing development of sociogenomics. By excavating the social through a multispecies ${ }^{7}$ history of interactions between social insects and biologists situated in particular institutional settings, we can begin to explore the kind of social, and indeed, the kind of individual, that are being effected via the evolving apparatus of contemporary sociogenomics.

It is not a mere coincidence that the very term "sociogenomics" was first articulated by Gene Robinson, one of the most pre-eminent social insect biologists of our time. Social life has been the raison d'être of the field of social insect biology since its beginnings as a field-based natural history, overlapping with the period when sociology itself emerged, in distinction from biology, as a discipline concerned with the social circumscribed within human spheres. Since then, social insects have been key mediators trafficking theories and practices concerning social organization and social life back and forth between the biological sciences

\footnotetext{
${ }^{4}$ Dalton Conley and Jason Fletcher, The Genome Factor: What the Social Genomics Revolution Reveals about Ourselves, Our History, and the Future (Princeton: Princeton University Press, 2017).

${ }^{5}$ Catherine Bliss, Social By Nature: The Promise and Peril of Sociogenomics (Stanford, California: Stanford University Press, 2018).

${ }^{6}$ Sara Whatmore, "Materialist Returns: Practising Cultural Geography In and For a More-than-human World," Cultural Geographies 13, no. 4 (2006): 600-609.

7 I do not engage in this essay with the burgeoning literature on multispecies relations in the anthropological, and historical studies of science. See for example, Matei Candea, "Habituating Meerkats and Redescribing Animal Behaviour Science," Theory, Culture \& Society 30, no. 7/8 (2013): 105-128.
} 
and social sciences. ${ }^{8}$ What "epistemic forms" and infrastructures — and associated politics - if any, have social insect studies brought to bear upon the emerging interdiscipline of sociogenomics, about what is, and how is sociality? In turn, how have epistemic loci shifted in biological studies of the social with the advent of postgenomic epistemic forms? I begin by providing some background about sociogenomics and a brief review of emerging social scientific critiques.

\section{Nature-nurture in sociogenomic terms}

Practitioners of sociogenomics like to raise the nature/nurture debate to make the point that phenotype is neither the product of nature nor of nurture but of nature and nurture. Historian and philosopher of science Evelyn Fox-Keller explains the puzzling persistence of this debate and the "discovery" that both "nature" and "nurture" matter, as the result of semantic slippage in the linguistic practices of scientists. ${ }^{10}$ In the postgenomic context, nurture or environment is understood to influence phenotypic outcomes through environmentally responsive modifications to an individual's genome that are termed "epigenetic." ${ }^{11}$ The DNA inside of cells is not simply a linear, two-dimensional sequence of letters interspersed with special segments called genes coding for proteins, but a dynamic four-dimensional molecule, whose temporal folding and dynamic structuring in response to particular cellular and organismal environments, as well as in response to particular developmental and ecological contexts, ${ }^{12}$ render some parts of it into functionally coding genes and others not. Epigenetics is the very basis upon which the same DNA sequence manifests differently when situated in a neuron as opposed to being in an immune cell. In the prevailing epigenomic paradigm of which sociogenomics is a key part, not just the DNA sequence, but also social and ecological exposures through epigenetic modifications of DNA sequences can be passed on to future generations.

In the postgenomic era, we thus have an understanding of variations in a trait being the product of variations in DNA sequence and variations in environmental influence, which are mediated via shifts in the gene expression. Historian of science Hannah Landecker argues that this post-

\footnotetext{
${ }^{8}$ Diane M. Rodgers, Debugging the Link Between Social Theory and Social Insects (Baton Rouge: Louisiana State University Press, 2008).

9 Sainath Suryanarayanan and Daniel Lee Kleinman, "B(e)ecoming Experts: The Controversy Over Insecticides in the Honey Bee Colony Collapse Disorder," Social Studies of Science 43, no. 2 (2013): 215-240.

${ }^{10}$ Evelyn Fox-Keller, The Mirage of Space Between Nature and Nurture (Durham: Duke University Press, 2010).

${ }^{11}$ Eva Jablonka and Marion J. Lamb, Evolution in Four Dimensions: Genetic Epigenetic, Behavioral, and Symbolic Variation in the History of Life (Cambridge: The MIT Press, 2005).

12 Scott Gilbert, "Ecological Developmental Biology: Developmental Biology Meets the Real World," Developmental Biology 233, no. 1 (2001): 1-12.
} 
genomic understanding of environmental influence is very much a "post-cybernetic"13 one, in the sense of conceiving social influences as discrete packets of information-signals - which are "transduced" as cascades of biochemical signals via receptors embedded on membranous surfaces. Indeed, signal transduction pathways are key epistemic objects for sociogenomicists who want to investigate how social factors such as neighborhood quality, poverty, exposure to chemical toxicants such as lead, domestic violence and affluence get "under the skin"14 and interact with "genetic risk" profiles. For example, they want to understand why some children who were exposed to lead, domestic violence or neglect remain resilient while others suffer. ${ }^{15}$

Critics have expressed serious concerns about the "nature-first"16 approach being advanced by practitioners of sociogenomics, in which social phenomena "outside" of individuals such as race, poverty, and chemical pollution are turned into biological phenomena "inside" of individuals' bodies. As a result of this "molecularization" ${ }^{17}$ of the social, issues that could be addressed through social-structural changes instead become potential pharmaceutical targets. For example, when going to college is framed as a health issue that affects an individual's quality of life and longevity, the genomic correlates of those disinclined to attend college could be treated with a cocktail of customized drugs, further blurring the socially constructed divide between therapy and enhancement.

The movement of the social from the "outside" of bodies to "inside" of bodies, which is constituted by the discursive and material apparatuses of postgenomic fields such as sociogenomics and toxicogenomics, ${ }^{18}$ synergizes with neoliberal market practices that devolve responsibility and accountability from collectives and institutions to individuals. ${ }^{19}$ However, the shift from the outside to the inside is not a one-to-one translation of the social, but rather a transduction of the social, in the form of meaning-laden signals evolved via natural selection. ${ }^{20}$ This transduction of the environmental and social from the collective outside to the "deep" genomic inside, orchestrated by postgenomic epistemic forms, and its attendant

${ }^{13}$ Hannah Landecker, "The Social as Signal in the Body of Chromatin," in Biosocial Matters: Rethinking Sociology-Biology Relations in the Twenty-First Century, eds. Maurizio Meloni, Simon Williams, and Paul Martin, 79-99 (West Sussex, UK: Wiley Blackwell, 2016), 80.

${ }_{14}$ W. Thomas Boyce, Marla B. Sokolowski, and Gene E. Robinson, "Toward a New Biology of Social Adversity," Proceedings of the National Academy of Sciences 109, suppl. 2 (2012): 17143-8.

15 Conley and Fletcher, The Genome Factor.

16 Bliss, Social By Nature: The Promise and Peril of Sociogenomics, 20.

${ }^{17}$ Lily E. Kay, The Molecular Vision of Life: Caltech, The Rockefeller Foundation and the Rise of the New Biology (New York: Oxford University Press, 1993. Also Bliss, Social By Nature: The Promise and Peril of Sociogenomics, 6. Sara Shostak, Exposed Science: Genes, the Environment, and the Politics of Population Health (Berkeley and Los Angeles: University of California Press, 2013), 19.

18 Ibid.

${ }^{19}$ Melinda Cooper, Life As Surplus: Biotechnology \& Capitalism in the Neoliberal Era (Seattle: University of Washington Press, 2008).

${ }^{20}$ Landecker, "The Social as Signal in the Body of Chromatin." 
implications for new forms of discrimination, is not specific to sociogenomics and is rather a general feature of post-cybernetic post-genomics in the twenty-first century. For Catherine Bliss, this transduction is emphatically a gross reduction of "human nature to a mere sequence of genes." ${ }^{21}$

Like philosopher of science Phillip Kitcher's dissection of "Pop" sociobiology, Bliss has advanced a valuable critique of "Pop" sociogenomics - the version of sociogenomics that advances "grand claims about human nature and human social institutions." 22 There are, of course, compelling reasons for deconstructing the popular version of sociogenomics. After all, twentyfirst century sociogenomics is emerging from the long shadow of human eugenics and the racist and misogynist pogroms of experimentation and sterilization it justified in the twentieth century. Moreover, much of the hype in the genomics industry, mass media and the scientific media concerns utopian and dystopian imaginaries of humankind, and is rife with slippage around fundamental terms such as genes and genetic risk. ${ }^{23}$ At the same time, human-centered (anthropocentric) critiques of sociogenomics rest on a taken-for-granted separation between human and non-human, and imply that the methods, claims and attendant implications of sociogenomics and sociobiology may not be so problematic as long as they are confined to non-human bodies and ecologies; what is questioned is the scope and applicability to human realms.

Sociogenomics is much broader than the narrowly human configurations in which it has been critiqued. Fundamental understandings of human bodies tend to be based on a conceptual and operational opposition to, and contiguity with, non-human bodies, ${ }^{24}$ and in this sense, a multispecies excavation of the genealogies of sociogenomics can fracture and re-focus what it means for "human" bodies, cultures and politics. In the following pages, I attend to the multispecies relationships that have constituted shifting understandings of what is, and how is, the nature of social. In particular, I explore how historical interactions between biologists and social insects have shaped theories, approaches and interpretations regarding the social, and concomitantly, the individual, and how these interact with postgenomic epistemic forms in sociogenomics. I show how the evolving socio-technical apparatus of sociogenomics orchestrates transversal articulations across insect and human genomes that generate a molecular-cybernetic version of social complexity, and which end up eschewing the complex histories and ecologies that sociogenomics set out to incorporate. In the conclusion, I return to the pressing issues of politics and justice raised by emerging STS analyses of the postgenomic life sciences. I argue

${ }^{21}$ Bliss, Social By Nature: The Promise and Peril of Sociogenomics, inner cover.

22 Philip Kitcher, Vaulting Ambition: Sociobiology and the Quest For Human Nature (Cambridge: The MIT Press, 1985), 15.

${ }^{23}$ Fox-Keller, The Mirage of Space Between Nature and Nurture.

${ }^{24}$ Giorgio Agamben, The Open: Man and Animal (Stanford, CA: Stanford University Press, 2004). 
that sociogenomics doubly displaces "the individual" through an inward molecularization and an outward hypermachinization - a dynamic recombination of computational assemblages across market, state, and civil-society apparatuses - to underpin a hyper-machinic sociality in which individuals are transiently reconfigured as multi-dividuals situated in market-driven transactions.

\section{Social insect biology: A key epistemological and ontological foundation of sociogenomics}

Social insects have long served as quintessential societies in "nature," and as vehicles for legitimating historically specific cultural understandings of human social dynamics. ${ }^{25}$ Among scientists, social insects have historically occupied a central place as "epistemic objects" in the "experimental systems" that biologists constructed to understand the parameters, mechanisms, and evolution of varieties of social life. ${ }^{26}$ Scientists too have drawn explicit parallels between insect societies and human societies. ${ }^{27}$ The parallel evolution of complex forms of social organization in social insects and humans is seen by scientists to be a key causal factor in the ecological dominance of these groups..$^{28}$ Indeed, social insects may arguably be the most human of non-humans, because "like human beings, [social insects] can create civilizations." ${ }^{29}$

In the following pages, I draw on the writings of social insect biologists since the late nineteenth century, who were situated mainly in the United States and parts of western Europe, as well as on historical analyses of biologists' practices, to trace the shifting epistemic forms of social insect biology. Historical developments in the research norms, practices and interpretations regarding social life were not the inevitable products of progress in science and technology. I use

\footnotetext{
${ }^{25}$ Rodgers, Debugging the Link Between Social Theory and Social Insects.

${ }^{26}$ Hans-Jörg Rheinberger, Toward a History of Epistemic Things: Synthesizing Proteins in the Test Tube (Stanford: Stanford University Press, 1997), 28-31.

${ }^{27}$ Charlotte Sleigh, Six Legs Better: A Cultural History of Myrmecology (Baltimore: The Johns Hopkins University Press, 2007).

${ }^{28}$ For a contemporary example, see Hagai Y. Shpigler, Michael C. Saula, Frida Corona, Lindsey Block, Amy Cash Ahmed, Sihai D. Zhao, and Gene E. Robinson, "Deep Evolutionary Conservation of Autism-related Genes," Proceedings of the National Academy of Sciences 114, no. 36 (2017): 9653-8. Also Sleigh, Six Legs Better.

29 Bert Hölldobler and Edward O. Wilson, The Superorganism: The Beauty, Elegance, and Strangeness of Insect Societies (New York: W.W. Norton \& Company, Inc., 2009), xviii. For an alternative perspective on sociality in insects that are considered to be not truly social, see James T. Costa, The Other Insect Societies (Harvard University Press, 2006).
} 
table $1^{30}$ as an analytic orienting device, a tool that charts the continuities and discontinuities in key categories and associated research approaches that I believe informed American and western European biologists' understandings of sociality since the late-nineteenth century. As Table 1 outlines, indeed, no one singular notion, and way of unpacking, social life emerges over the course of the past two centuries of biological research on social phenomena. Instead, varied intellectual currents of capturing and leveraging "the social" crystallize in interplay with prevailing political and cultural notions about community, cooperation and competition. Some of these currents intersect, amplify, and transform into programmatic waves that have spilled across multiple cultural fields, and have had lasting effects on research norms, practices and discourses regarding the evolution and nature of social life as such.

30 Table 1 takes inspiration from feminist STS scholar Donna Haraway's use of a "taxonomic" chart to periodize the twentieth-century foundations of biological discourses on race, population and genome. Donna Haraway, "Race: Universal Donors in a Vampire Culture," in Modest Witness@Second Millenium. FemaleMan @_Meets_OncoMouseTM (New York, London: Routledge, 1997), 213-65. 


\begin{tabular}{|c|c|c|c|c|c|c|c|}
\hline Social & Psyche & $\begin{array}{c}\text { Super- } \\
\text { organism }\end{array}$ & $\begin{array}{l}\text { Molecular } \\
\text { Genetic }\end{array}$ & Cybernetic & $\begin{array}{c}\text { Socio- } \\
\text { biological }\end{array}$ & $\begin{array}{l}\text { Plastic and } \\
\text { complex }\end{array}$ & $\begin{array}{l}\text { Socio- } \\
\text { genomic }\end{array}$ \\
\hline $\begin{array}{l}\text { Estimated } \\
\text { period }\end{array}$ & $\begin{array}{c}1870 \text { s } \\
\text { onward }\end{array}$ & 1910-1930s & $\begin{array}{l}\text { 1930s } \\
\text { onward }\end{array}$ & $\begin{array}{c}1950 \text { s } \\
\text { onward }\end{array}$ & $\begin{array}{c}\text { Late } 1960 \mathrm{~s} \\
\text { onward }\end{array}$ & $\begin{array}{l}1980 \text { s } \\
\text { onward }\end{array}$ & $\begin{array}{c}\text { Late } 1990 \mathrm{~s} \\
\text { onward }\end{array}$ \\
\hline Approach & $\begin{array}{l}\text { Comparative } \\
\text { Psychological }\end{array}$ & $\begin{array}{c}\text { Natural } \\
\text { history } \\
\text { Non- } \\
\text {-Darwinian }\end{array}$ & $\begin{array}{c}\text { Physiological, } \\
\text { genetic, } \\
\text { mechanistic } \\
\text { Neo- } \\
\text {-Darwinian }\end{array}$ & $\begin{array}{c}\text { Mathematical, } \\
\text { computa- } \\
\text { tional }\end{array}$ & $\begin{array}{c}\text { Neo- } \\
\text {-Darwinian } \\
\text { Experimental } \\
\text { reductionist } \\
\text { Genetic }\end{array}$ & $\begin{array}{l}\text { Neo- } \\
\text {-Darwinian } \\
\text { and non- } \\
\text {-Darwinian, } \\
\text { genetic, } \\
\text { behavioral } \\
\text { ecology }\end{array}$ & $\begin{array}{c}\text { Evolutionary, } \\
\text { comparative, } \\
\text { genomic, } \\
\text { computa- } \\
\text { tional data } \\
\text { science }\end{array}$ \\
\hline $\begin{array}{l}\text { Research } \\
\text { Focus }\end{array}$ & $\begin{array}{l}\text { Instinct, } \\
\text { Plasticity, } \\
\text { Social } \\
\text { Instinct } \\
\text { (modifiable), } \\
\text { windows } \\
\text { into the } \\
\text { unconscious } \\
\text { of human } \\
\text { nature }\end{array}$ & $\begin{array}{c}\text { Inter- } \\
\text {-individual } \\
\text { cooperation, } \\
\text { coordination } \\
\text { and com- } \\
\text { munication, } \\
\text { behavioral } \\
\text { interactions, } \\
\text { resource } \\
\text { exchange }\end{array}$ & $\begin{array}{c}\text { Intra- } \\
\text {-individual } \\
\text { mechanisms } \\
\text { of dominance, } \\
\text { social } \\
\text { hierarchy }\end{array}$ & $\begin{array}{l}\text { Communica- } \\
\text { tion, } \\
\text { information, } \\
\text { signal } \\
\text { transduction }\end{array}$ & $\begin{array}{l}\text { Kin selection } \\
\text { Inclusive } \\
\text { fitness, } \\
\text { Genetics } \\
\text { of social } \\
\text { behavior, } \\
\text { selfish } \\
\text { genes }\end{array}$ & $\begin{array}{c}\text { Gene- } \\
\text {-environment } \\
\text { interaction, } \\
\text { Evolutionary } \\
\text { developmen- } \\
\text { tal genetics, } \\
\text { Condition- } \\
\text {-specific } \\
\text { phenotypic } \\
\text { novelty, } \\
\text { Emergence } \\
\text { and self- } \\
\text {-organization }\end{array}$ & $\begin{array}{c}\text { Dividuated } \\
\text { sociogenome } \\
\text { in interaction } \\
\text { with hyper- } \\
\text { machinic } \\
\text { systems; } \\
\text { Genetic tool } \\
\text { kits for } \\
\text { novelty } \\
\text { seeking, } \\
\text { social re- } \\
\text { sponsiveness, } \\
\text { aggression } \\
\text { etc., genetic } \\
\text { networks. }\end{array}$ \\
\hline $\begin{array}{l}\text { Cultural and } \\
\text { political con- } \\
\text { cerns }\end{array}$ & $\begin{array}{l}\text { Victorian and } \\
\text { imperial no- } \\
\text { tions of race, } \\
\text { intelligence, } \\
\text { eugenics }\end{array}$ & $\begin{array}{l}\text { First World } \\
\text { War, pacifist } \\
\text { agendas of } \\
\text { American } \\
\text { biologists, } \\
\text { the Bolshevik } \\
\text { revolution, } \\
\text { eugenics }\end{array}$ & $\begin{array}{c}\text { Great } \\
\text { Depression, } \\
\text { Establishment } \\
\text { of fascist } \\
\text { movements } \\
\text { and regimes, } \\
\text { eugenics }\end{array}$ & $\begin{array}{l}\text { Cold War, } \\
\text { Military- } \\
\text {-industry } \\
\text { complex, } \\
\text { backlash } \\
\text { against Nazi } \\
\text { eugenics; } \\
\text { eugenics is } \\
\text { delegitimized } \\
\text { as an institu- } \\
\text { tion }\end{array}$ & $\begin{array}{l}\text { Civil Rights } \\
\text { Movement } \\
\text { Anti-war } \\
\text { movements } \\
\text { Environmen- } \\
\text { tal movement } \\
\text { Science for } \\
\text { the People }\end{array}$ & $\begin{array}{c}\text { Neo- } \\
\text {-liberalization, } \\
\text { and } \\
\text { capitalizing } \\
\text { on dispositifs } \\
\text { of } \\
\text { uncertainty, } \\
\text { adaptation, } \\
\text { and resilience. }\end{array}$ & $\begin{array}{c}\text { Surveillance } \\
\text { and sousveil- } \\
\text { lance, rise of } \\
\text { authoritarian } \\
\text { regimes in } \\
\text { response to } \\
\text { public } \\
\text { disaffection } \\
\text { with } \\
\text { neoliberal } \\
\text { austerity } \\
\text { programs, } \\
\text { 2nd Great } \\
\text { Recession }\end{array}$ \\
\hline
\end{tabular}

Table 1. Interconnected themes concerning the biological nature of the social and the individual spanning the late-nineteenth and early twenty-first centuries, with social insects as models of instinct, as superorganisms, as physiological models of social dominance, as cybernetic machines, as genetic models of altruism, as models of phenotypic plasticity and complexity, and as machinic-genomic entities of sociogenomics. 


\section{The social psyche}

Prior to World War I, field studies on social insects and their solitary relatives took comparativepsychological approaches that deemed ants and termites, while being incapable of human-like intelligence, to be the highest possible manifestations of evolved instinct in the nonhuman realm. Instinct was a key epistemic thing in early scientific studies of insect societies ${ }^{31}$ and it comprised the irrational animal unconscious within humans. In this framework, social insects such as ants became model exemplars of the human mind and instinct, mainly among European scientists. Studying ants was seen as shedding light on the psychology of human behavior because ants were understood to be controlled by their instincts. Late nineteenth century field experiments reflected Victorian clinical and psychological understandings of instinct as inherited, and more or less inevitable in expression. But at the same time, instinct was recognized as being modifiable through education/training and in that sense, endowed with some degree of plasticity. Comparative observations of "primitive" extant forms of ants with more recent forms allowed nineteenth century psycho-biologists to make claims about the evolution of instincts from inferior to superior races and reflected Victorian colonial understandings of racial hierarchies. ${ }^{32}$ Post-Darwin, comparative-psychological studies of social insects took on an evolutionary edge as well. Pioneering observations of nest-building behavior in social wasps by colonial workers such as Emile Roubaud suggested a plasticity to "social instinct" that was apparently not exhibited by social insects' solitary counterparts. ${ }^{33}$ While the notion that irrational human social behavior is driven by evolved instincts may no longer be in vogue, ${ }^{34}$ late nineteenth-century and early twentieth-century field studies on ants and social wasps advanced the establishment of comparative psychological and evolutionary approaches, and a notion of plasticity in social evolution, which as I show later in this paper, are mainstays in sociogenomics today.

\section{The social superorganism}

According to sociobiologists E. O. Wilson and Bert Hölldobler, "[t] he history of insect sociobiology can be fruitfully viewed as the evolution of the superorganism concept as it has waxed and waned and waxed again." 35 The notion of society as "superorganism" was

\footnotetext{
${ }^{31}$ Sleigh, Six Legs Better.

32 Ibid.

${ }^{33}$ Ibid., 56-59.

${ }^{34}$ For a study of how the concept of instinct became of decreasing concern in the development of the field of social psychology, see Diane M. Rodgers. "Insects, Instincts and Boundary Work in Early Social Psychology," History of the Human Sciences 26, no. 1 (2012): 68-89.

${ }^{35}$ Hölldobler and Wilson, The Superorganism, 11.
} 
established during the interwar years by the U.S. ant biologist William Morton Wheeler. ${ }^{36} \mathrm{~A}$ superorganism is a tightly-knit independent unit comprised of closely cooperating individual organisms that operate like the cells or tissues in an organism. ${ }^{37}$ A superorganism undergoes division of labor, growth, reproduction and shifts in behavior, size and structure that are akin to those experienced by an individual organism. Wheeler noted that calling a social insect colony a superorganism was not merely an analogy to a person. Wheeler's holistic notion of an ant society as superorganism was supported by his studies of "trophallaxis" 38 the exchange of semi-liquid exudates between adults and immatures and between adults within a colony-which constituted the economic and communicative glue binding together parts of the superorganism. Wheeler's superorganism was resolutely non-Darwinian in its emphasis on cooperation rather than competition as the central feature of social life. It resonated with the non-Darwinian research agendas of prominent animal ecologists, and with the anti-war agendas of American biologists, who were committed to a pacifist politics of democracy, community and cooperation. ${ }^{39}$ The originator of the superorganism concept was also an enthusiastic eugenicist, and links between holistic superorganisms and eugenics are illustrated in Wheeler's discussion of reproductive and sterile female "castes" in the social Hymenoptera. ${ }^{40}$ Commenting on sterilization and the existence of sterile females that fulfill the role of non-reproductive females (workers) and reproductive females (queens) that mate and generate new offspring in ant societies, Wheeler wrote: "This remarkable method of reducing the reproductivity of a society, whilst insuring its nutritive success, is of no little interest at the present time. It is probably not a coincidence that we should be most diligently discussing eugenics, or the restriction of reproduction to the sane in mind and body, at a time when we are also most exercised by the high cost of living." ${ }^{41}$ In contrast to the prevailing ideas of animal ecologists that cooperative society originated in loose intra-specific or interspecific associations between individuals, ${ }^{42}$ Wheeler noted the importance of family origins for sociality, emphasizing that "maternity is the pivotal instinct" in the development of all insect societies. ${ }^{43}$ Wheeler's concept of superorganism, with its holistic and eugenic leanings, as well

\footnotetext{
36 William Morton Wheeler, “The Ant-Colony As An Organism,” Journal of Morphology 22, no. 2 (1911): 307-325. Also, William Morton Wheeler, The Social Insects: Their Origin and Evolution (London: Kegan Paul, Trench and Company, 1928).

${ }^{37}$ Hölldobler and Wilson, The Superorganism.

${ }^{38}$ Wheeler, The Social Insects.

39 Gregg Mitman, The State of Nature: Ecology, Community, and American Social Thought, 1900-1950 (Chicago and London: The University of Chicago Press, 1992).

${ }^{40}$ Insect order comprising of wasps, bees, ants.

${ }^{41}$ William Morton Wheeler, "Notes About Ants and Their Resemblance to Man," The National Geographic Magazine 23, no. 8 (1912): 731-766, on 742-743.

${ }^{42}$ Mitman, The State of Nature, 80.

43 Wheeler, "Notes About Ants and Their Resemblance to Man," 743.
} 
as his emphasis on the familial and maternal origins of "true societies" 44 were fundamental drivers of the field of insect sociobiology over the next century going into sociogenomics.

\section{The social within}

Amidst the first great economic recession of the twentieth century and the specters of fascism and totalitarianism gripping United States and Europe, the holistic notion of superorganism began to wane. The "resemblance" 45 that Wheeler had noted with positive valence between a matriarchal ant colony as superorganism and communist society carried within it not just a dynamic of cooperation but also of domination, hierarchy and eugenic control seemingly required for maintaining stable cooperation. In the 1930s and 1940s, Italian ethologist Leo Pardi pioneered mechanistic and physiological approaches to social dynamics of cooperation. Based on his experiments on "primitively eusocial" Polistes wasps, Pardi argued for the occurrence of linear hierarchies of social dominance, with the egg-laying queen on top of the chain-of-command, controlling and eliciting cooperation through aggressive physical coercion of her daughters and co-habitants. ${ }^{46}$ In showing in an invertebrate society what the US ecologist Clyde Allee had observed in vertebrate groups, Pardi's research reinforced the comparative parallels between vertebrate and insect societies. To explain the correlation he had observed between dominance status and reproductive status in Polistes, Pardi took an "etho-physiological approach." ${ }^{47}$ He postulated physiological mechanisms related to individual ovarian development as underpinning the emergence of social hierarchy between individuals. Pardi's research set the stage for Polistes wasps to become a "model genus" for subsequent research on the physiological and genomic "underpinnings" of social dominance as key mechanisms for maintaining cooperation in societies. ${ }^{48}$

During the same period, from the 1930s onward, the rise of a "molecular vision of life" signaled an epistemological and infrastructural shift in the Euro-American biological research enterprises resulting in the reification of "the molecular level as the essential locus of life." ${ }^{\prime 9}$ "The rising

44 Hölldobler and Wilson, The Superorganism, 8-9. Aggregations of organisms are considered by sociobiologists to truly social (eusocial) if they exhibit three criteria: non-reproductive individuals and reproductive individuals; two or more generations of adults co-occur in the same groups; and nonreproductive individuals help with nest maintenance and offspring care (workers).

45 Wheeler, "Notes About Ants and Their Resemblance to Man," 743.

46 Guido Caniglia, "Understanding Societies from Inside the Organisms. Leo Pardi's Work on Social Dominance in Polistes Wasps (1937-1952)," Journal of the History of Biology 48, no. 3 (2015): 455-86.

47 Ibid., 455.

48 Jenny Jandt, Elizabeth A. Tibbets, and Amy L. Toth, "Polistes Paper Wasps: A Model Genus For the Study of Social Dominance Hierarchies,” Insectes Sociaux 61, no. 1 (2014): 11-27.

${ }^{49}$ Kay, The Molecular Vision of Life, 7. 
molecular genetic paradigm fueled the "the modern synthesis" of Darwinian theory, ${ }^{50}$ which offered new light on the mechanisms of inter-individual variation and differential survival, with DNA seen as the originary source of that variation, and population as the fundamental category of evolutionary change. "Gr "Group selection" versus "individual selection" models based on population genetics became the pre-eminent prism through which American animal biologists examined and debated the evolution and dynamics of sociality. ${ }^{52}$ In group selection, the super-organism (now subsumed under population), not the individuals comprising the group, was the prime target of natural selection. Group selectionists such as Wynne C. Edwards, Clyde Allee, Sewall Wright and Alfred Emerson posited genes for altruism, and offered models in which groups that had many individuals with altruistic genes had a higher likelihood of survival and would hence be favored by natural selection, compared to groups with self-interested individuals fending only for themselves. In the 1930s going into the 1940s, the United States and Europe was gripped by rising movements of fascism and increasing skepticism toward arguments that justified the extermination of certain individuals as good for the group, or the fatherland. ${ }^{53}$ In this political and cultural context, group selectionist models wilted ${ }^{54}$ in the face of individual selection models that posited the individual organism as the main unit of natural selection. Maynard-Smith created models based on games-theory ${ }^{55}$ to show, for example, that the invasion of a "cheater" gene in a population of altruistic individuals would soon lead to the takeover of that population by cheaters, thus undermining group selectionist explanations. G. C. Williams deployed the Occam's Razor-the notion that given two competing explanatory solutions for the same problem, the simpler solution is the more likely one to occur in reality - to conclude that individual-selection models are sufficient to explain the evolution of altruistic behavior and preclude the need for group-level models. ${ }^{56}$

In the new world order that was forming by the end of the Second World War and the beginning of the Cold War, it was "the individual" that arose in prominence above "the group." With the neo-Darwinian modern synthesis re-instating competition as the fundamental basis of life itself, sociobiology crystallized as a field that took the "altruism out of altruism." ${ }^{57}$ The rise of sociobiology as the premier field concerned with the biology of the social was prefigured by William Hamilton's theoretical and social wasp research leading to his famous notion of

\footnotetext{
${ }^{50}$ Julian Huxley, Evolution: The Modern Synthesis (New York: John Wiley \& Sons Inc., 1963 [1942]).

${ }^{51}$ Mitman, The State of Nature, 5.

52 Ibid., 5-6.

53 Donald Worster, Nature's Economy: A History of Ecological Ideas (Cambridge University Press, 1985).

${ }^{54}$ Mitman, The State of Nature.

55 Richie Nimmo, "Enfolding the BioSocial Collective: Ontological Politics in the Evolution of Social Insects," Humanimalia 9, no. 2 (2018): 28-46.

56 George.C. Williams, Adaptation and Natural Selection (Princeton: Princeton University Press, 1996 [1966]).

${ }^{57}$ Mitman, The State of Nature, 8.
} 
"genetic evolution of social behavior." ${ }^{\text {8 }}$ Hamilton innovated on J. B. S. Haldane's relatednessbased model in which altruism - understood as "an activity that benefits another individual (the "recipient") to the seeming disadvantage of the altruist" selection if the recipient of the altruistic act was sufficiently closely related to the altruist, so that the recipient's survival benefited the genes shared with the altruist. Using Sewall Wright's "Coefficient of Relationship" as a measure of the relatedness between individuals, Hamilton developed the concept of inclusive fitness, which is the sum total of an individual's own (direct) fitness plus its influence on the fitness of indirectly related kin. ${ }^{60}$ For example, a sterile female worker honey bee with zero direct fitness could still accrue some indirect fitness through her relatedness to the queen's offspring that she helped raise. Hamilton's research with social wasps was pivotal to his honing the inclusive fitness concept ${ }^{61}$ Hamilton's inclusive fitness concept, along with Maynard-Smith's kin selection concept, became the bases not only for establishing that altruism has a genetic explanation, but also for the separation of the "environmental" component from the "genetic" component. The epistemic locus of understanding the social had definitively shifted from a non-Darwinian notion of superorganism based on cooperation to neo-Darwinian genes using individuals as vessels to compete for survival. This epistemic shift did not remove, so much as displace eugenic interests to the molecular level of DNA and genes. ${ }^{62}$ As Hamilton himself notes in his autobiographical Narrow Roads of Gene Land, at the time he was developing his ideas of genetic evolution of altruism, he was a firm believer in the positive effects of eugenics and an ardent admirer of Francis Galton, the founder of eugenics and biometry. ${ }^{63}$

\section{The cybernetic social}

At the same time that genetic models of social evolution and social life were ascendant, firstorder cybernetics and information theory had emerged from the ferment of scientific activity during World War II with the goal of engineering new systems of military communication and control. ${ }^{64}$ By the end of the war, German ethologist Karl von Frisch had gained widespread recognition in the United States for his field experiments suggesting that honey bees

\footnotetext{
${ }^{58}$ William D. Hamilton, “The Genetical Evolution of Social Behaviour. I," Journal of Theoretical Biology 7, no. 1 (1964): 1-16.

59 Ernst Mayr, The Growth of Biological Thought: Diversity, Evolution, and Inheritance (Cambridge: Harvard University Press, 1982), 598.

${ }^{60}$ Hamilton, "The Genetical Evolution of Social Behaviour. I," 1.

${ }^{61}$ Guido Caniglia, "Investigating Wasp Societies: A Historical and Epistemological Study" (PhD diss., Arizona State University, 2016), 41-86.

${ }^{62}$ Kay, The Molecular Vision of Life.

${ }^{63}$ Hamilton, "The Genetical Evolution of Social Behaviour. I."

${ }^{64}$ Sleigh, Six Legs Better.
} 
communicated the location, direction and distance of local nectar sources to their hive-mates through dances that conveyed symbolic information that could be construed as language. U.S. military funders took an interest in research on insect communication and orientation in the context of developing sonar, radar and predictive weapons systems. Social insects, in particular, because of their highly developed systems of organization, communication and coordination, became "cybernetic models" for "the design of machines with colony-like properties of problem solving." ${ }^{35}$ Cyberneticists developed the notion that "the living system may be regarded as a machine that stores and processes information." ${ }^{16}$ Cybernetic systems approaches in the United States were synergetic with corporate interests in the optimal management of their work-force. ${ }^{67}$ The cybernetic characterization of humans as parts of machinic wholes echoed Frederick Taylor's "principles of scientific management," who in his concerns with how to properly organize "ordinary men" to cooperate efficiently noted that "in the past the man has been first; in the future the system must be first." 68 Thus, neither for the first time nor the last, the figure of the machine emerged as a strong link connecting humans and social insects. Inspired by the work of European ethologists such as Niko Tinbergen, cyberneticians reinvigorated the study of instinct, understood now as being "derived from inherited patterns of behavior" and entailing "automatic chains of stimulusresponse activities which proceed in certain circumstances to be elicited and to be performed without significant variation." ${ }^{69}$ Machine-like processes are "rooted, above all, in mathematics and $\operatorname{logic} " 70$ and in this regard, cybernetics brought principled, mathematical, computational, probabilistic, and information-theoretic approaches to understanding human and nonhuman collectives conceived of in terms of systems, codes and signals. The emphasis on "systems" meant that cybernetics, or at least a certain version of it, was not mutually exclusive from the holistic concept of superorganism, which had by now waned. Indeed, without meaningful transmission of signals-measurable bits of information between senders and receiversthere could be no communication, and thereby no coordination, cooperation and collective problem solving.

\footnotetext{
${ }^{65}$ Ibid., 169.

${ }^{66}$ Lila L. Gatlin, Information Theory and the Living System (New York: Columbia University Press, 1972), 17.

${ }^{67}$ By contrast, cybernetics in the Soviet context was developed as a "science in the service of communism." Slava Gerovitch, From Newspeak to Cyberspeak: A History of Soviet Cybernetics (Cambridge: MIT Press, 2002).

${ }^{68}$ Frederick Winslow Taylor, The Principles of Scientific Management (New York: W.W. Norton \& Company, 1967 [1911]), 7.

${ }^{69}$ F. H. George, Cybernetics and Biology (Edinburgh and London: Oliver \& Boyd, 1965), 55.

${ }^{70}$ Ibid., 20.
} 


\section{The sociobiological social}

The formation of sociobiology as "the systematic study of the biological basis of all social behavior" "11 was deeply influenced by the establishment of the "modern synthesis," genetic theories of sociality, first-order-cybernetic approaches to living systems and the rise of "zoosemiotics"72 as a discrete discipline analyzing animal communication. In the 1950s and 1960s, Edward O. Wilson, widely known today as the founding father of sociobiology, was conducting breakthrough studies of communication and control in ant societies and identified pheromones - chemical signals released as glandular secretions which were implicated in mediating a wide array of social interactions ranging from colony defense to task stimulation to food recruitment and even inhibition and stimulation of the developmental and behavioral maturation of particular individuals. ${ }^{73}$ In contrast to the centralized, physical control mechanisms that Leo Pardi postulated in "primitively eusocial" Polistes wasps, Wilson's "advanced eusocial" ants exhibited more subtle, de-centralized systems of chemical control, which presumably precluded the need for overt, physical coercion, and enabled an exponential increase in colony size. In his pheromone research, the mathematically inclined Wilson deployed cybernetic epistemic forms such as measuring the amounts of transmitted information in bits laid down by the odor trail of a fire ant. ${ }^{74}$ Wilson also exemplified a commitment to genetical theories of sociality. Echoing Richard Dawkins' highly reductive and geno-centric notion of "the selfish gene," 75 Wilson wrote: "the organism is only DNA's way of making more DNA,"76 as opposed to an organicist perspective that DNA is simply only the organism's way of making more organisms.

It is no surprise then that Wilson argued against Wheeler's notion of superorganism. In Insect Societies, Wilson's important precursor to Sociobiology, Wilson wrote: "The superorganism concept faded not because it was wrong but because it no longer seemed relevant...the concept offers no techniques, measurements, or even definitions by which the intricate phenomena in genetics, behavior, and physiology can be unraveled." 77 Opposing the vague and "liberalized holism" of the superorganism approach, Wilson laid out an experimental reductionist agenda for insect sociobiology: “...the current generation of students of social insects...saw its [sociobiology's] future in stepwise experimental work on narrowly conceived problems" with the belief that "there exists among experimentalists a shared faith that characterizes the

\footnotetext{
${ }^{71}$ Edward O. Wilson, Sociobiology: The New Synthesis (Cambridge: Harvard University Press, 1975), 4.

72 Thomas Sebeok, “Animal Communication,” Science 147, no. 3661 (1965): 1006-1014.

${ }^{73}$ Edward O. Wilson, The Insect Societies (Cambridge: Harvard University Press, 1971).

${ }^{74}$ Ibid.

${ }^{75}$ Richard Dawkins, The Selfish Gene (Oxford: Oxford University Press, 1976).

76 Wilson, Sociobiology: The New Synthesis, 3.

77 Wilson, The Insect Societies, 318-319.
} 
reductionist spirit in biology generally, that in time all piecemeal analyses will permit the reconstruction of the full system in vitro." ${ }^{78}$ Sociobiology became established as an intellectual field firmly situated in a neo-Darwinian paradigm — sociality was generated to varying degrees of complexity by interactions between genetic, environmental and historical constraints on the species and population structure, whereby natural selection acted upon genes that conferred inclusive fitness benefits of altruism to individuals in kin-based groups. Since social insect species in existence display the spectrum of modalities of social living-from rudimentary, highly flexible (primitively eusocial) groups to extremely large colonies with distinct morphological and behavioral specializations-they are seen as immensely valuable models for understanding the evolutionary, ecological and developmental drivers of sociality. The die had been cast for examining social behavior in a familial-kin-based, gene-environment framework, with insect societies playing a key role in the initiation and development of this experimental reductionist approach to sociality.

The sociobiological social appears as a linear hierarchy of evolutionary gradations, a "social ladder" from solitary or non-social ancestral varieties to less derived varieties of "simple" societies, from which arose the highly derived varieties of "advanced" or "complex" societies. ${ }^{79}$ This hierarchically differentiated conception of sociality and its implicit parallels to gradations of human sociality from primitive tribes to advanced civilizations were already evident in earlier phases of social insect studies. For example, in 1912, Wheeler wrote "the ethnic history of ants parallels that of man to the extent that these insects were originally flesh-eating hunters, then shepherds of food-producing herds, and finally agriculturists, and that they have been compelled to pass through these stages." ${ }^{80}$ Wheeler had made these parallels between ants and humans in an earlier era when racial, eugenic, and colonial agendas were taken for granted. Wilson, however, did not fare so well publicly, when he extended his reductionist sociobiology from social insects to humans.

Sociobiology's extension of genetic theories of social behavior to humans brought it into the controversial space of human behavior that was occupied by behavioral genetics. ${ }^{81}$ While sociobiology had turned the social from superorganism to individual kin, the social ladder (from simple to complex, primitive to advanced) remained intact. However, the broader political culture had shifted. On the heels of vibrant civil rights, anti-war movement and environmental movements Wilson's extension of a reductionist neo-Darwinian sociobiology to human social behavior catalyzed public outrage. Activists belonging to the organization

\footnotetext{
78 Ibid., 319.

${ }^{79}$ Howard E. Evans, “The Evolution of Social Life in Wasps," in Selected Readings in Sociobiology, ed. James H. Hunt, 137-148 (New York: McGraw Hill Book Company, 1980), 139.

${ }^{80}$ Wheeler, "Notes About Ants and Their Resemblance to Man," 741.

${ }^{81}$ Aaron Panofsky, Misbehaving Science: Controversy and Development of Behavioral Genetics (Chicago and London: The University of Chicago Press, 2014).
} 
Science for the People used direct action to disrupt professional science meetings to advance their critique of the academic-military-industrial complex "arguing that interlocking systems of capitalism, racism, sexism, and imperialism would have to be eliminated in order for the benefits of science to extend beyond the ruling classes." ${ }^{22}$ The Sociobiology Study Group of Science for the People called out sociobiologists' claims about the biological basis of social behavior as "another biological determinism." ${ }^{83}$ The Sociobiology Study group took issue with the Wilson's "evolutionary analogy" between animal and human societies, and "the legitimating loops" 84 through which cultural phenomena such as slavery, division of labor became naturalized"discovered" in animal societies - and then became used to justify inequality, dominance hierarchies, and the status quo as "natural." 85 The group noted the complete absence of any direct evidence of genes coding for human collective behaviors such as xenophobia, religion, ethics, social dominance, hierarchy formation, slavery etc. and concluded that "sociobiologists can adduce no facts to support the genetic basis for human social behavior." ${ }^{86}$ Ernst Mayr, one of the architects of the neo-Darwinian modern synthesis, disagreed with the accusations of genetic determinism of behavior being leveled at E. O. Wilson and other sociobiologists. He wrote: "All they [sociobiologists] have said, and one can argue about the validity of this claim, is that much of man's social behavior has a genetic component. But this is not the same as genetic determinism. It must be remembered that a behavior may be controlled by 'closed' or 'open' programs and that even open programs have a considerable genetic component." ${ }^{37}$ At the same time, an institutional struggle for authority within Harvard University was not entirely unrelated to the wide-ranging intellectual broadside delivered by Wilson's Harvard colleagues, Richard Lewontin and Stephen Jay Gould, who questioned the neo-Darwinian adaptationist and molecular genetic assumptions of sociobiology, and argued against what they perceived to be a "doctrine of DNA" 88 being propagated by Wilson and other biologists. Like behavioral genetics, by the early 1980s, sociobiology found itself in a public quagmire of culturally taboo research on the biological and genetic basis of human behavior. Unlike behavioral genetics though, sociobiology continued to develop through less-controversial research programs on non-humans, in which social insects continued to be prime models for testing theories of kinselection, inclusive fitness and the genetic basis of sociality.

82 Kelly Moore, Disrupting Science: Social Movements, American Scientists and the Politics of the Military, 1945-1975 (Princeton: Princeton University Press, 2008), 159.

83 Sociobiology Study Group of Science for the People, "Sociobiology-Another Biological Determinism," in Selected Readings in Sociobiology, ed. James H. Hunt, 415-423 (New York: McGraw Hill Book Company, 1980), 417.

${ }^{84}$ Rodgers, Debugging the Link Between Social Theory and Social Insects, 182.

${ }^{85}$ Sociobiology Study Group of Science for the People, "Sociobiology_Another Biological Determinism."

${ }^{86}$ Ibid., 419.

${ }^{87}$ Mayr, The Growth of Biological Thought, 598-599.

${ }^{88}$ Richard C. Lewontin, Biology As Ideology: The Doctrine of DNA (New York: Harper Collins, 1992). 


\section{Plastic and complex social}

Sociobiologist's reductive emphases on geno-centrism and natural selection and their inability to account for complex patterns of social behavior spurred alternative sociobiological research agendas in the 1980s, which took "phenotypic flexibility," "phenotypic plasticity"90 and complexity as key epistemic objects. Mary Jane West-Eberhard drew on her extensive field studies of "primitively eusocial" wasps, in which an individual wasp could express a worker/ helper phenotype or queen/egg-layer phenotype, and this phenotypic flexibility is dependent on developmental circumstances, not on differences in DNA sequence between the two phenotypes. West-Eberhard termed "phenotypic plasticity" this reversible and irreversible capacity of an organism to respond to "an internal or external environmental input with a change in form, state, movement or rate of activity." ${ }^{\text {11 }}$ Through her framework of phenotypic plasticity, West-Eberhard sought to reinstate the environment, not as background or noiseas had been wont in genocentric sociobiology_but as a key player in social and behavioral evolution. West-Eberhard observed in her now classic Developmental Plasticity and Evolution: "While debate raged over genetic determinism and human sociobiology, evolutionary biologists went about testing the predictions of kin-selection theory ...the result was not massive documentation of genetic determinism in behavior, but rather the opposite-massive documentation of a heretofore widely underestimated capacity for adaptive conditionsensitive behavior and development." ${ }^{22}$ West-Eberhard's grand synthesis drew heavily on evolutionary-developmental biology (evo-devo), a field integrating evolutionary and genetic studies with studies of embryological, developmental mechanisms toward forging "integrative" understandings of why organisms behave the way they do. For a large portion of the twentieth-century, developmental biology and embryology had been considered marginal, and at best of indirect relevance to evolutionary understandings. ${ }^{93} \mathrm{~A}$ shift in this situation was indicated by the evolutionary biologist Stephen Gould's ${ }^{94}$ re-working of the notion of "heterochrony....an evolved shift in the timing and expression of a trait or a set of traits," 95 along with the identification in 1984 of highly conserved homeobox genes, identical stretches of DNA linked to the embryonic development of body parts that were found in organisms

\footnotetext{
${ }^{89}$ Mary Jane West-Eberhard, "Flexible Strategy and Social Evolution," in Animal Societies: Theories and Facts, eds. Y. Ito, J. L. Brown, J. Kikkawa, 35-51 (Tokyo: Japan Science Society Press, 1987), 35.

${ }^{0}$ Mary Jane West-Eberhard, "Phenotypic Plasticity and the Origins of Diversity," Annual Review of Ecology and Systematics 20 (1989): 249-278.

${ }_{11}$ Mary Jane West-Eberhard, Developmental Plasticity and Evolution (New York: Oxford University Press, 2003), 33.

92 Ibid., 5.

93 Michel Morange, "How phenotypic plasticity made its way into molecular biology," Journal of Bioscience 34, no. 4 (2009): 495-501.

${ }^{4}$ Stephen Gould, Ontogeny and Phylogeny (Cambridge, Belknap Press, 1977).

95 West-Eberhard, Developmental Plasticity and Evolution, 22.
} 
ranging from plants to insects to humans. ${ }^{96}$ In tandem, these suggested: (1) the occurrence of "genetic tool-kits," nearly identical stretches of DNA that are shared across widely disparate taxa, which in some cases are involved in the same functions in very different organisms (such as eye formation), and in other cases are involved in very different functions, and (2) that novel social phenotypes can evolve from environmentally induced heterochronic shifts in the timing and expression of genetic tool-kits during development. West-Eberhard conceptualized the development and evolution of social phenotypes in cybernetic terms as recombinations of quasi-autonomous "modular subunits" determined by bifurcating "switches or decision points" that organize organismal development along particular morphological, physiological or behavioral paths. ${ }^{97}$ Switch-point regulation is typically dependent on the conditions shaped by the internal environment, social environment and external environment, and genotypic influences on regulation are typically "highly polygenic." 98

The importance of evo-devo for re-thinking sociality is illustrated best in West-Eberhard's ovarian ground plan hypothesis, which proposes that eusociality arose in social insects mainly via simple changes in the regulation — timing and expression — of the maternal physiology and behavior of solitary ancestors, as opposed to de novo evolution of social genes. ${ }^{99}$ Gro Amdam and Robert Page built on West-Eberhard's hypothesis and their research on honey bees to propose a "reproductive ground plan hypothesis," 100 according to which a shift in the timing and expression of key reproductive hormones from adult stages to immature stages triggered the formation of young adults that expressed behavioral traits such as maternal care linked with reproductive maturity but bypassed other stages that are characteristic of the ancestral pre-reproductive period. These adults expressed maternal care toward siblings, and became workers. In these notions about the evolutionary emergence of a novel worker phenotype from heterochronic shifts in the developmental genetics of maternal traits in solitary ancestors, we can see the return of Wheeler's emphasis on the importance of the maternal instinct for social life.

In parallel to the increasing recognition of the necessity of environmental influences and phenotypic plasticity in understanding social behavioral phenomena, the 1980s and 1990s witnessed the rise of systematic research programs on complex social systems and networks, which eventually fueled a renewed cybernetic focus on the superorganism-the collective colony-level of social phenomena that Wheeler had proposed in 1928 as an integrated and

\footnotetext{
96 Morange, "How phenotypic plasticity made its way into molecular biology."

97 West-Eberhard, Developmental Plasticity and Evolution, 68.

${ }^{98}$ Ibid.

99 West-Eberhard, "Flexible Strategy and Social Evolution."

${ }^{100}$ Robert E. Page Jr. and Gro V. Amdam, “The Making of a Social Insect: Developmental Architectures of Social Design,” BioEssays 29, no. 4 (2007): 334-343.
} 
independent entity-in contrast to the individual, gene-centric and neo-Darwinian frame of sociobiology. A significant development in this regard was the establishment of the Santa Fe Institute in Santa Fe, New Mexico in 1984-an interdisciplinary gathering of physicists, mathematicians, computer scientists, biologists and social scientists interested in understanding the universal principles and fundamental rules shaping complex adaptive systems in physical, biological and cultural worlds. ${ }^{101}$ Institute scientists looked over the Chaco Canyon, which had been the ground on which ancient Anasazi cultural forms had evolved, and imagined "hunting bands out there, groups of individuals, each able to do all the tasks in the group." Then, "they [the hunting bands] interact with each other, you get specialization, then... Bang! ...phase transition...a new level of social organization, a higher level of complexity." ${ }^{102}$ Reading these lines inspired social wasp biologist Robert Jeanne, a former graduate student of E. O. Wilson's- to wonder along the margins of his copy of Lewin's book, if this "phase transition" could also apply to the evolutionary switch from "simple" to more "complex" insect societies. ${ }^{103}$

In the 1980s as well, ant biologist Deborah Gordon began conducting ground-breaking graduate research on harvester ants, which led her to conclude, in contrast to E. O. Wilson, that "an ant's response to a chemical cue was not fixed, but depended on what the ant was doing," which in turn was affected by its interactions with other ants and its environment. ${ }^{104}$ Gordon's subsequent research on the "self-organizing" properties of the complex social systems of ants, over a period of three decades to the present, suggested that when "local interactions" between component parts-"neurons in the brain, the cells in the immune system, the ants in the colony" - based on "simple algorithms" (such as yes or no) occur in a "complex environment," it leads to the "emergence" of "coordinated behavior of the whole" system. ${ }^{105}$ In contrast to prevailing notions of the occurrence of specialized castes that are sorted according to size to perform particular tasks, Gordon observed that removal of ants of one size caused ants of other sizes to switch their tasks. While social insect biologists gained conceptual tools from complexity sciences, computationists became inspired by the shared principles underlying "distributed processes" in social insect colonies, immune cell dynamics, traffic patterns and stock markets. Honey bee swarms and ant colonies have inspired computer simulations and models of "swarm intelligence" for engineers and artificial intelligence researchers, some of who are interested in designing wireless devices and automatons that can perform task

${ }^{101}$ Roger Lewin, Complexity: Life At the Edge of Chaos (New York: Collier Books, 1992).

102 Ibid., 22.

${ }^{103}$ Ibid.

${ }^{104}$ Deborah M. Gordon, "Dynamics of task switching in harvester ants," Animal Behaviour 38, no. 2 (1989): 194-204.

${ }^{105}$ Deborah M. Gordon, Ants at Work: how an insect society is organized (New York: Free Press, Simon and Schuster Inc. 1999). Deborah M. Gordon, Ant Encounters: Interaction Networks and Colony Behavior (Princeton: Princeton University Press, 2010), 7-8, 19. 
allocation, specialization and coordination. ${ }^{106}$ These endeavors to mine the collective behaviors of social insects for enhancing information and communication technologies are of particular interest to the U.S. military and defense industry, who for example, are keen on developing algorithms to synchronize collective action between remotely-controlled military drones to carry out coordinated drone strikes. ${ }^{107}$ The concomitant rise of computers and supercomputers capable of highly computationally intensive operations in "real-time" along with advances in statistics have fueled an explosion in computational network approaches to social behavior, in sociology and in social insect biology. The emergence of a renewed cybernetic research program concerning social insects shapes an understanding of the social as an emergent outcome of simple algorithmic interactions between differentiated and flexible machinic entities situated in complex environments.

While the resurgence of sociobiological research on phenotypic plasticity and supra-organismal complexity in understanding sociality are potential antidotes to genetic and biological determinism, there are reasons to be cautious. Melinda Cooper ${ }^{108}$ argues that the historical shift from the welfare state to the neoliberal state was marked by heterogeneity, uncertainty and flexibility, and oversaw the correlated rise of non-equilibrium models of chaos and complexity. Under neoliberalization, market efficiency increasingly becomes the basis of governance, and risk and responsibility are devolved from institutions to individuals. In this context, the notion of plasticity - an opening up of the individual body, rendering it porous and malleable to social and environmental interventions - synergizes with neoliberal approaches that couch health and well-being in discourses and practices of individual self-care and responsibility. ${ }^{109}$ Plasticity becomes a commodity—tailored drugs, neural enhancement devices, Baby Einstein appsdesigned to modulate the phenotypic profiles of those who can afford it.

\section{Sociogenomic social}

Writing at the end of the twentieth century, Gene Robinson, by then already a star in honey bee biology, coined the term "sociogenomics" in the process of envisioning a far-reaching research agenda for "integrative studies" of the molecular genetics of social behavior within

\footnotetext{
${ }^{106}$ For example, see Manuele Brambilla, Eliseo Ferrante, Mauro Birattari, and Marco Dorigo, "Swarm Robotics: A Review From the Swarm Engineering Perspective," Swarm Intelligence 7, no. 1 (2013): 1-41. ${ }^{107}$ Jake Kosek, "Ecologies of Empire: On the New Uses of the Honeybee," Cultural Anthropology 25, no. 4 (2010): 650-678.

${ }_{108}$ Cooper, Life As Surplus: Biotechnology \& Capitalism in the Neoliberal Era.

${ }_{109}$ Victoria Pitts-Taylor, "The Plastic Brain: Neoliberalism and the Neuronal Self," Health 14, no. 6 (2010): 635-652.
} 
an ecological context $(1997,1998: 461,1999: 202,204) .{ }^{110}$ By this time, the human genome project (HGP), an international research effort to map the entire genetic sequence of Homo sapiens, was nearing completion. Under the aegis of the HGP, behavioral genetics, whose eugenicist and racist roots had shaped its controversial development and fragmentation, was experiencing a resurgence. ${ }^{111}$ Robinson directly addressed concerns among "lay public" about the specter of "biological determinism" raised by behavioral genomics, by making a case for studying "social behavior" because it is "especially sensitive to environmental influence." 112 Thus, from its very inception, Gene Robinson framed sociogenomics in opposition to genetic and biological determinism. In defining it as a field that would showcase the importance of the environment on the plasticity of behavioral development, Robinson sought to advance the development of twenty-first-century behavioral genomics as a valid science and a socially responsible one too.

Drawing on evo-devo research, Robinson positioned "genes" as a "common language" that fuses - (1) individual-level "mechanistic analyses" to population-level "evolutionary analyses"; (2) the environment, including the "social environment," to phenotypes via "socially responsive genes and gene actions"; and (3) diverse and disparate organismal groups such as insects and humans through the concept of conserved genetic toolkits. ${ }^{113}$ On the cusp of the postgenomic century, Robinson's vision of sociogenomics resonated with an expanding view of DNA, not as some innate, fixed essence determining an organism's destiny, but as a dynamic, reactive molecule shaped by ecological, evolutionary and developmental forces to effect complex, condition-specific behaviors, including social life. Importantly, this expansive view of genes re-positioned genes as barometers of environmental influence.

Based on accumulating genetic analyses of social behavior, Robinson was convinced "that many genes must be studied to understand a particular behavior," 114 as opposed to the singlegene focused "candidate-gene paradigm." ${ }^{115}$ In this regard, he saw the HGP as an essential

\footnotetext{
${ }^{110}$ Gene E. Robinson, Susan E. Fahrbach, and Mark L. Winston, "Insect Societies and the Molecular Biology of Social Behavior," BioEssays 19, no. 12 (1997): 1099-1108; Robinson, "From Society to Genes with the Honey Bee," 461; Gene E. Robinson, "Integrative Animal Behaviour and Sociogenomics," Trends in Ecology \& Evolution 14, no. 5 (1999): 202-205, on 202, 204.

111 Aaron Panofsky, "From Behavior Genetics to Postgenomics," in Postgenomics: Perspectives on Biology After the Genome, eds. Sara S. Richardson and Hallam Stevens, 150-173 (Durham and London: Duke University Press, 2015).

112 Robinson, "From Society to Genes with the Honey Bee," 456.

113 Robinson, "Integrative Animal Behaviour and Sociogenomics," 202.

${ }^{114}$ Ibid., 204.

115 Gene E. Robinson, "Sociogenomics and the Dynamic Genome: A New Perspective on Nature and Nurture," Inaugural Lecture, Center for the Economics of Human Development, Biology and Behavior Forum, University of Chicago, May 11, 2018. https://cehd.uchicago.edu/?page_id=1313 (accessed October 19, 2018).
} 
incubator of technologies and insights for simultaneously analyzing large numbers of genes. ${ }^{116}$ Soon after Robinson's prescient call for sociogenomics, the genomes of laboratory animal models such as the round worm C. elegans, fruit fly, and mouse were sequenced, followed by the publication of complete draft of the human genome in 2003. Robinson co-led the Honeybee Genome Sequencing Consortium which published the first draft of the honey bee genome in 2006.

In promoting sociogenomics, Robinson and other social insect biologists have positioned social insects, and in particular, honey bees as exemplars. ${ }^{117}$ Honey bees "exhibit the full range from genes to society" ${ }^{\prime 18}$ and biologists have access to rich repositories of experimental and observational knowledge across this range, and increasingly, genome sequence data. Robinson's extensive neuroendocrine and genetic research in honey bees extended "under the skin" parallels between insect societies and human societies. ${ }^{119}$ Robinson suggests that E. O. Wilson had gotten into trouble for making comparative assertions between nonhumans and humans, because these assertions were beyond science's ability in 1975, but "we're now at a moment with genomics that we can get it right with respect to understanding human nature... and the sociogenomics paradigm gives us an opportunity" to "bridge the gaps" between the body of animal work and human behavior. ${ }^{120}$

Gene Robinson's sociogenomics research with honey bees makes a systematic case for drawing justifiable comparisons between social insects and humans based on the rationale of highly conserved genes. For example, Robinson's group recently identified a "deep evolutionary conservation of autism-related genes" between humans and honey bees. ${ }^{121}$ The scientists identified a fraction of worker bees that were consistently "socially unresponsive" to experimentally imposed "social challenge" stimuli and "social opportunity" stimuli, despite being seemingly healthy, compared to other worker bees. Using RNA sequencing to quantify the number of mRNA transcripts ${ }^{122}$ —an indicator of which genes are "turned on" or "turned

\footnotetext{
116 Robinson, "Integrative Animal Behaviour and Sociogenomics."

117 Amro Zayed and Gene E. Robinson, "Understanding the Relationship Between Brain Gene Expression and Social Behavior: Lessons from the Honey Bee," Annual Review of Genetics 46 (2012): 591-615.

118 Robinson, "Sociogenomics and the Dynamic Genome."

119 Biologist's investigations of the mechanistic links between social behavior, hormones and brain processes also implicate neurobiology and neurogenomics in sociogenomics. Also, Maurizio Meloni, "The social brain meets the reactive genome: neuroscience, epigenetics and the new social biology," Frontiers in Human Neuroscience 8, no. 309 (2014), doi: 10.3389/fnhum.2014.00309.

120 Robinson, "Sociogenomics and the Dynamic Genome."

121 Shpigler et al., "Deep Evolutionary Conservation of Autism-related Genes."

122 A gene (DNA sequence) gets "transcribed" by cellular components into messenger RNA (mRNA) strands, which are then "translated" by other cellular components into the particular set of amino acids that the particular DNA sequence codes.
} 
off"- they generated for the socially unresponsive and responsive bees "gene expression profiles" of their honey bee brain regions involved in "sensory integration and social behavior." 123 The scientists created a list of differentially expressed genes (DEG) — genes that showed up as being expressed or not expressed only in the socially unresponsive bees, compared to the socially responsive bees. They utilized statistical tests and algorithms for aligning sequence reads, analyzing gene expression levels compared to reference honey bee genome sets, and for assessing the extent of overlap between the DEG list of socially unresponsive bees and previously published DEG lists associated with human autism-spectrum disorder, Alzheimer's disease and schizophrenia diagnoses. Observing "significant overlap" only between the socially unresponsive bee DEG list and autism DEG list, Shpigler et al. concluded: "[d]espite profound differences between honey bee and human societies, we have documented strong similarities in the genes associated with social responsiveness." ${ }^{124}$ While these similarities could have arisen "from either common ancestry or convergent evolution," ${ }^{125}$ Robinson clarified that Shpigler et al. (2017) were not claiming that socially unresponsive honey bees are autistic, but that genes that are involved in one component of autism-social unresponsiveness-are ancient, and can be involved in "evolutionarily independent instantiations of social behavior and social responsiveness." ${ }^{26}$

Shpigler et al. exhibit how the advent of novel epistemic forms of association based on "regimes of statistical computation" 127 have advanced the comparative logic of human-bee parallels in sociogenomics. Writing with computer scientists and information scientists in PLoS Biology, sociogenomics founder Gene Robinson makes a case for genomics as a "Big data science" that surpasses "other Big data domains" such as astronomy, You Tube and Twitter in terms of its demands on data acquisition, storage, distribution, and analysis. ${ }^{128}$ Robinson's colleague and computer scientist Saurabh Sinha states elsewhere that "[c] omputational methods that help uncover regulatory networks and elements of gene expression from sequence and limited experimental data are ... in demand." ${ }^{129}$

However, emerging high-throughput computational and statistical methods for generating

${ }^{123}$ Shpigler et al., "Deep Evolutionary Conservation of Autism-related Genes."

${ }^{124}$ Ibid., 3.

${ }^{125}$ Ibid.

126 Robinson, "Sociogenomics and the Dynamic Genome."

127 David Golumbia, The Cultural Logic of Computation (Cambridge: Harvard University Press, 2009).

${ }_{128}$ Zachary D. Stephens, Skylar Y. Lee, Faraz Faghri, Roy H. Campbell, Chengxiang Zhai, Miles J. Efron, Ravishankar Iyer, Michael C. Schatz, Saurabh Sinha, and Gene E. Robinson, "Big Data: Astronomical or Genomical?," PLOS Biology 13, no. 7 (2015): e1002195, doi:10.1371/journal. pbio. 1002195 .

${ }^{129}$ Charles Blatti, Majid Kazemian, Scot Wolfe, Michael Brodsky, and Saurabh Sinha, "Integrating Motif, DNA Accessibility and Gene Expression Data to Build Regulatory Maps in an Organism," Nucleic Acids Research 43, no. 8 (2015): 3998-4012, on 3999. 
associations across large, heterogeneous and high-dimensional ${ }^{130}$ datasets are not without bias, and can end up excluding ecological influences in intriguing ways. For example, computational tests of overlap between DEG lists tend to be based on the assumption that "all genes evolved equally." 131 The same genes from different populations across species and even within the same species are known to vary in their "regulatory architecture, such as the number of transcription factor binding sites," which could affect "how flexible the transcription of a particular gene responds to changes in the cellular environment." ${ }^{\prime 32}$ Even though Shpigler et al.'s computational tests of overlap honey bee and human DEG lists accounted for cross-species differences such as "the number of genes in the background for the species," 133 Lawhorn et al. argue that "regulatory variability among genes leads to a systematic bias for concluding that DEG lists are more similar than expected by chance." 134 Sociogenomic analyses comparing genes and differentially expressed gene lists need to be interpreted with caution as they can eschew the organismal and ecological assemblages and developmental circumstances within which a particular DNA sequence becomes specified and regulated as a gene. ${ }^{135}$ Insect sociobiologists have pointed to the need for careful standardization of "omic" technologies and "a close dialog between social insect biologists, molecular biologists and bioinformaticians" to "future-proof genomic datasets within meaningful ecological contexts." ${ }^{136}$.

Social insect biologists Brian Johnson and Timothy Linksvayer have expanded the scope of the interpenetration between sociobiology and postgenomics by developing an integrative notion of "the socio-genome" that resurrects a cybernetic version of the superorganism. ${ }^{137}$ They draw on systems-theoretic metaphors and concepts to argue that a social system's solutions for engaging with its dynamic and unpredictable environment is a function of its size. For small colonies of

\footnotetext{
${ }^{130}$ High-dimensional means that the number of features in a given data set are more than the number of observations per feature.

${ }_{131}$ Chelsea M. Lawhorn, Rachel Schomaker, Jonathan T. Rowell, and Olav Rueppell, "Simple Comparative Analyses of Differentially Expressed Gene Lists May Overestimate Gene Overlap," Journal of Computational Biology 25, no. 6 (2018): 606-612, on 607.

${ }^{132}$ Ibid.

${ }^{133}$ Shpigler et al., "Deep Evolutionary Conservation of Autism-related Genes," 5.

134 Lawhorn et al., "Simple Comparative Analyses of Differentially Expressed Gene Lists May Overestimate Gene Overlap," 607 (my emphases).

${ }^{135}$ Furthermore, only mRNA transcripts with known related sequences in a reference genome set can be identified as potential genes. When scientists observe mRNA transcripts that shift in response to some experimental treatment but have no known gene in the reference genome to relate it to, it is difficult to estimates what the shift in expression of that mRNA means in terms of biological function.

${ }_{136}$ Patrick Kennedy, Gemma Baron, Bitao Qiu, Dalial Freitak, Heikki Helanterä, Edmund R. Hunt, Fabio Manfredini, Thomas O’Shea-Wheller, Solenn Patalano, Christopher D. Pull, Takao Sasaki, Daisy Taylor, Christopher D.R. Wyatt, and Seirian Sumner, "Deconstructing Superorganisms and Societies to Address Big Questions in Biology," Trends in Ecology \& Evolution 32, no. 11 (2017): 861-872, on 867.

${ }^{137}$ Brian R. Johnson and Timothy A. Linksvayer, "Deconstructing The Superorganism: Social Physiology, Groundplans, and Sociogenomics," The Quarterly Review of Biology 85, no. 1 (2010): 57-79, on 68.
} 
primitively eusocial Polistes wasps, the key evolutionary solution was "team-like societies"138 of relatively flexible individual generalists (recall the Sant Fe Institute scientist's musings about the phase transition from simple tribes to complex city-states). By contrast, for much larger colonies of Polybia wasps and honey bees, the key evolutionary solution was "factorylike societies" with "assembly-line dynamics" among behaviorally differentiated individuals; while extremely large ant colonies evolved "machine-like societies" with morphologically differentiated individuals, which are capable of task partitioning and coordination to carry out specialized roles in a tightly integrated manner (functionally analogy to cells in a multicellular organism). ${ }^{139}$ Observing that ground plan hypotheses may be robust explanations for the evolution of "division of labor" involving the formation of reproductive and non-reproductive worker phenotypes, Johnson and Linksvayer argued that coordination of tasks and activities between highly specialized individuals was an altogether different problem than that faced by solitary ancestors and hence required the evolution of entirely novel genetic networks constructed de novo from "a toolkit of previously independent sensory processes." ${ }^{140}$

With Johnson and Linksvayer, we thus see the refined integration of postgenomic, sociobiological and cybernetic conceptions, in which a "complex" society is conceived of as a machinic entity with multiple differentiated components that are tightly coordinated in dynamic feedback loops with its composite "socio-genome"-comprised of complex networks of environmentally and socially responsive genes within individuals shaping the expression of individual traits specific to the situation of the group, and at the same time shaping the social and environmental factors of the group, within which those genetic networks are situated. ${ }^{141}$ Thus, more than three decades after Wilson's ${ }^{142}$ dismissal of Wheeler's superorganism concept, sociobiologists along with Wilson himself ${ }^{143}$ have ironically turned again to the superorganism as a relevant entity for understanding social life. This is, however, not a turning back to Wheeler's organicist notion per se, but a turning toward a cybernetic, machinic version of the holistic superorganism.

\section{Conclusion}

The rise of sociogenomics might suggest a new phase in the evolving fields of knowledge concerning the nature and control of "the social"; a phase in which the chasms between biology and sociology, which have been iteratively constructed and policed for much of the

${ }^{138}$ Ibid., 61.

139 Ibid.

${ }^{140}$ Ibid., 67.

${ }^{141}$ Ibid., 68.

142 Wilson, The Insect Societies.

${ }^{143}$ Hölldobler and Wilson, The Superorganism. 
twentieth century, are now being filled largely, albeit unevenly, by bio-cybernetic "regimes of truth." 144 These new regimes of truth appear in fields such as economics and political science, whose provinces and concerns until recently used to be far removed from genes, DNA, and hormones. In this sense, sociogenomics reinforces for "the social" what Nikolas Rose observed with regards to "the human" in the twenty-first century, as being "all the more biological." ${ }^{45}$

Building on Rose, ${ }^{146}$ my contention throughout this paper has been that epistemic forms of social insect biology have deeply shaped biological instantiations of the social in contemporary sociogenomics. Epistemologically, sociogenomics entails a paired move away from the individual surface: an inward move, and a symmetric and unequal outward move. There is an inward move to the sociogenome-what STS scholars have called molecularization. With molecularization, the individual implodes into a genomic "dividual," 147 a "fractionated subject"148 who is dynamically composed, re-composed and de-composed as a mosaic of modular phenotypic traits such as aggressivity, stress, personality, happiness, novelty-seeking, and social responsiveness. Postgenomic epistemic forms and technologies strip individuals down to genomic dividualswhole genome sequences, gene expression profiles, reaction norms and polygenic risk scoresthat are more encodable, transmissible, replicable, and commodifiable compared to the messy complexities of tissues and bodies; and each of which can be malleable and plastic to varying degrees depending on the historical relationships, circumstances, contingencies and systems in which these phenotypes occur. ${ }^{149}$

Molecularization in sociogenomics is always already accompanied by a symmetric, and unequal, move outward from the individual—what one might call a hypermachinization. ${ }^{150}$ Here, the

\footnotetext{
${ }^{144}$ According to Michel Foucault, a regime of truth is the set of discourses accepted as true in a particular society, along with the techniques and institutions that enable one to separate the true from the false, and the status of those who are empowered to say what counts as true. See Michel Foucault, Discipline and Punish: The Birth of the Prison (New York: Vintage Books, 1995 [1977]).

${ }^{145}$ Nikolas Rose, The Politics of Life Itself: Biomedicine, Power, and Subjectivity in the Twenty-First Century (Princeton and Oxford: Princeton University Press, 2007), 20.

${ }^{146}$ Ibid.

${ }_{147}$ Gilles Deleuze, "Postscript on the Societies of Control," October 59 (Winter 1992): 3-7. on 5.

148 Louise Amoore, The Politics of Possibility: Risk and Security Beyond Probability (Durham: Duke University Press, 2013), 8.

149 The genome in this understanding is another surface-level, which refracts (or transduces) processes and experiences at the organismal surface in ways that do not necessarily entail a one-to-one mapping, but register, mediate, and co-produce shifts that an individual organism experiences. Even though epistemic forms in postgenomic fields such as sociogenomics "operate in a flattened world of surfaces rather than depths," the linguistic practices of sociogenomicists in peer-reviewed scientific publications are littered with conflations of surface and depth, in which genomic processes are "mechanisms" that are "deeper" and "underlying" - i.e. generative of organismal-level social processes.

150 The concept of hypermachinization introduces a spatio-temporal dynamism and contingency to the computational "hyperobjects" that are impinging upon, intruding in, our daily lives and future lives. See Timothy Morton, Hyperobjects (Minneapolis: The University of Minnesota Press, 2013).
} 
individual surface literally explodes into dividuated bits and streams of data distributed across "computational assemblages" 151 — health information systems, commodity markets, social media platforms, surveillance and security systems etc. By hypermachinization, I mean a dynamic (re-)combination of computational assemblages spanning market-, state- and socialmovement-infrastructures. I am arguing that sociogenomics performs a double-displacement of "the individual." With the emergence of novel epistemic forms of association such as predictive analytics and statistical machine learning algorithms, genomic dividuals are coconstituted with machinic life systems in globalized, securitized marketplaces. In the midst of the exploding deluge of information from the genomic to the astronomic, ${ }^{152}$ the ontological status of "the individual" does not drown or go away, but perhaps emerges anew.

The individual human as an autonomous, rational entity with agency, rights, responsibilities and dignity has been a long-standing and ambiguous figure of the liberal humanist institutions of Enlightenment Capitalism. ${ }^{153}$ The colonial, racist legacies upon which this white, masculine variety of "individual" has been built, foreclosed the status of individuality to those who were denoted never completely human, instigating struggles for racial, reproductive and environmental justice that we see playing out to this day. This enlightenment mode of individual bodies has been the subject of biopower in "disciplinary societies" since the eighteenth and nineteenth centuries, according to social theorist Michel Foucault. ${ }^{154}$ In the prison, the clinic, the school, the factory, individual bodies have been disciplined again and again to not deviate from their prescribed duties and responsibilities, and in this sense, as philosophers Gilles Deleuze $^{155}$ and Frèdèric Neyrat ${ }^{156}$ argue, disciplinary societies are driven by the past. Toward the end of the twentieth century, Deleuze observed a shift from "disciplinary societies" to "societies of control." 157 Here the operation of markets is now the instrument of social control, and the individual/mass pairing of disciplinary society gives way to dividual/market pairing that is subject to endless, undulatory control mediated by machinic technologies of corporate and state forces. ${ }^{158}$ In a neoliberalized state rife with markets capitalizing on uncertainty,

\footnotetext{
${ }^{151}$ John Johnston, The Allure of Machinic Life (Cambridge: The MIT Press, 2008).

152 Stephens et al., "Big Data: Astronomical or Genomical?"

153 To add to the "tired parade of posts" (Massumi), the "posthuman" (Braidotti) lurks in the postcybernetic and post-genomic variety of biology operating in sociogenomics. See Brian Massumi, What Animals Teach Us About Politics (Durham: Duke University Press, 2014), 92. Also, Rosi Braidotti, The Posthuman (Cambridge, UK: Polity Press, 2013).

${ }^{154}$ Foucault, Discipline and Punish: The Birth of the Prison.

155 Deleuze, "Postscript on the Societies of Control."

${ }^{156}$ Frèdèric Neyrat, "Occupying the Future: Time and Politics in the Era of Clairvoyance Societies," in The Present of the Future, eds. Susanne Witzgall and Kerstin Stakemeier, 79-90 (Chicago: The University of Chicago Press, distributed for Diaphanes, 2018).

157 Deleuze, "Postscript on the Societies of Control."

${ }^{158}$ Ibid.
} 
plasticity and resilience, the focus becomes real-time control of the present in the now. ${ }^{159}$ This is not to claim that archives from the past or possibilities from the future are no longer relevant. Indeed, "control societies" are also what Neyrat calls "clairvoyance societies" 160 in that they are not only oriented to controlling the real-time presencing of virtual and actual worlds, but also toward controlling future possibilities through anticipatory data mining and predictive analytics. This new kind of society, which for me sociogenomics underpins through molecularization and hypermachinization, enacts a kind of anticipatory control of possibilities that forecloses certain futures and enables others in the present for certain bodies that are always already categorized in historical and real-time transactions and that become part of the machine libraries of future-control. Here, a new kind of individual appears-which is made and un-made locally, globally, as a transiently integrated multi-dividuation of genetic risk profiles, life signatures, hyperlink clicks, electronic health records, and digital traces flowing unevenly through social media interactions, commodity transactions, physician visits, genealogical associations on ancestry.com, Fitbit logs, border-crossings, CCTV footage and the like- what might be called, a transient multidividual, ${ }^{161}$ whose exploding bits exceed and at the same time are integrated and controlled by dynamic mediations that constantly (re-)enable and (re-)enact complex productive environments oriented toward market-compliant, valuedriven interactions. ${ }^{162}$ Sociogenomics is then part of these cultures of control and clairvoyance, in which present and anticipatory controls are exercised through ordinary, routine, seductive means and taken up in interested ways by citizens. ${ }^{163}$

I suspect that some of the anxieties and concerns ${ }^{164}$ about sociogenomics (and related postgenomic fields) are related to the political consequences of these paired epistemo-ontological transformations of the individual and the social. How individuals matter in the evolving machinic-sociogenomic framework, especially those belonging to historically marginalized groups, is of serious concern. A growing body of work in critical studies of data science shows how machine learning algorithms and predictive analytics can reproduce toxic legacies of racial capitalism, since these computational tools for predicting future transactions and interactions depend on historical data of interactions between bodies that are always already marked as black or colored and associated with a particular suite of infractions, incarcerations and punishments

\footnotetext{
159 Neyrat, "Occupying the Future: Time and Politics in the Era of Clairvoyance Societies."

160 Ibid.

161 The term "transient multidividual" emerged in personal conversations with Frèdèric Neyrat, whose critical feedback to the originally submitted version of my essay has been important for clarifying parts of my conclusion.

${ }^{162}$ On digital platforms such as Twitter and You Tube, it is difficult to even know whether an individual account is a machinic bot impersonating an actual person or an actual person impersonating a bot.

163 Rob Kitchin, The Data Revolution, 1st ed. (Los Angeles, London, New Delhi: SAGE Publications Ltd., 2014).

${ }^{164}$ Bliss, Social By Nature: The Promise and Peril of Sociogenomics; Shostak, Exposed Science.
} 
by military-state-corporate apparatuses. ${ }^{165} \mathrm{Here}$, not all bodies passing through the same places would undergo the same kinds of dividual fragmentations, integrations and capitalizations. Along with the enclosure and potential foreclosure of "social structures" that sociogenomic molecularization would entail, we must also consider the ways in which genomic dividuals in the form of genetic risk scores, molecular profiles of stress, happiness and aggression get transiently integrated with dividuated bits from other computational assemblages to create particular kinds of multidividuals linked to real bodies, whose variegated presents and futures are rendered worthy of dying and living. The epistemo-ontological displacement of the individual into transiently existing multi(genomic)dividuals situated in and co-constituted with hypermachinizing assemblages generates new surface-layers of mediation between genotypic-environmental variations, which are of interest for technoscientific, corporate and military control as well as for resistance and activism. ${ }^{166}$

In this paper, I traced biologist's shifting conceptions of social life and societies in nature, showing how they have evolved from organicist, non-Darwinian notions of society as superorganism to neo-Darwinian, cybernetic and postgenomic conceptions of society as a hypermachinic life-system in feedback loops with socio-genomes (Table 1). I have attempted to show how the thick and shifting traffic of insectan epistemic forms about the nature of the social have intersected with postgenomic forms to shape the prevailing epistemology, ontology and accompanying politics of sociogenomics. It is my contention that the most unsettling and troubling aspects of sociogenomics lie not in its "genetic determinism," but rather in its genetic and biological indeterminism-in the unexpected associations and ramifications of transversal articulations between sociogenomic profiles and other "life signatures"167 toward advancing cultures of control. What kinds of mechanisms of power and resistance, and what kinds of transverse and perverse realities emerge from the genomic-machinic assemblages that sociogenomics and other postgenomic fields are beginning to articulate? These are questions that I believe require our sustained collective and critical attention.

\footnotetext{
${ }^{165}$ For example, see Amoore, The Politics of Possibility; Evgeny Morozov, "The rise of data and the death of politics," The Guardian, July 19, 2014, https://www.theguardian.com/technology/2014/jul/20/riseof-data-death-of-politics-evgeny-morozov-algorithmic-regulation (accessed January 9, 2019); Julia Angwin, Jeff Larson, Surya Mattu, and Lauren Kirchner, "Machine Bias," ProPublica, May 23, 2016, https://www.propublica.org/article/machine-bias-risk-assessments-in-criminal-sentencing (accessed January 9, 2019).

166 On the matter of resistance and activism related to postgenomic knowledge making and molecularization, see Sara Shostak, "Environmental justice and genomics: Acting on the futures of environmental health," Science as Culture 13, no. 4 (2004): 539-562.

${ }^{167}$ Amoore, The Politics of Possibility, 24.
} 


\section{Acknowledgements}

I am thankful to Frèdèric Neyrat, Katarzyna Beilin and the two anonymous reviewers for their valuable comments.

\section{Competing interests}

The author has declared that no competing interests exist.

\section{Funding}

This research was not funded by any external means. 